\title{
Geobacillus debilis sp. nov., a novel obligately thermophilic bacterium isolated from a cool soil environment, and reassignment of Bacillus pallidus to Geobacillus pallidus comb. nov.
}

\author{
Ibrahim M. Banat, Roger Marchant and Thahira J. Rahman \\ School of Biomedical Sciences, University of Ulster, Coleraine, County Londonderry BT52 1SA, \\ Northern Ireland, UK
}

Correspondence

Ibrahim Banat

IM.Banat@ulster.ac.uk

\begin{abstract}
Several aerobic, motile, rod-shaped, thermophilic, spore-forming Geobacillus bacteria predominantly giving a Gram-positive staining reaction were isolated from a cool soil environment in Northern Ireland and taxonomically investigated. Two isolates, F10 and $\mathrm{Tf}^{\top}$, showed low $16 \mathrm{~S}$ rRNA gene sequence similarity to recognized members of the genus Geobacillus. Phylogenetic tree investigation using neighbour-joining, maximum-likelihood and parsimony methods indicated that strains $\mathrm{F} 10$ and $\mathrm{Tf}^{\top}$ represent a single novel species, for which the name Geobacillus debilis sp. nov. is proposed, with type strain $\mathrm{Tf}^{\top}\left(=\mathrm{DSM} 16016^{\top}=\mathrm{NCIMB} 13995^{\top}\right)$ and which belongs to a subgroup of the genus Geobacillus comprising Geobacillus toebii and Geobacillus caldoxylosilyticus. However, G. debilis showed closest affinities to Bacillus pallidus, which we propose should become Geobacillus pallidus comb. nov.
\end{abstract}

Over a number of years, the large and diverse grouping of bacteria in the genus Bacillus has been progressively subdivided into the novel genera Alicyclobacillus, Paenibacillus, Brevibacillus, Aneurinibacillus, Virgibacillus, Salibacillus, Gracilibacillus, Ureibacillus and, most recently, Geobacillus (Nazina et al., 2001). These novel genera are based around separate phylogenetic groups derived from 16S rRNA gene sequence information. The original genus Bacillus contained aerobic and facultatively anaerobic, rod-shaped, Gram-positive (or Gram-variable) endospore-forming bacteria (Claus \& Berkeley, 1986).

Many of the organisms previously classified in the genus Bacillus are thermophilic, aerobic, spore-forming organisms, which fall into genetic groups 1 and 5 . There have been a number of taxonomic studies of the thermophilic bacilli, which retained these organisms within the genus (White et al., 1993; Rainey et al., 1994). The thermophiles in group 5 have been defined as 'a phenotypically and phylogenetically coherent group of thermophilic bacilli displaying very high similarity among their $16 \mathrm{~S}$ rRNA sequences (98.5-99.2\%)' (Nazina et al., 2001). These observations led this group of workers to erect the novel genus Geobacillus with Geobacillus stearothermophilus as the type species. The two novel species they described (Geobacillus subterraneus and Geobacillus uzenensis) were

The GenBank/EMBL/DDBJ accession numbers for the 16S rRNA gene sequences of $\mathrm{F} 10$ and $\mathrm{Tf}^{\mathrm{T}}$ are AJ564608 and AJ564616, respectively. isolated from subterranean petroleum reservoirs, geothermal locations providing an ideal source of thermophilic micro-organisms. In addition, Nazina et al. (2001) transferred some existing Bacillus species into the new genus as G. stearothermophilus, Geobacillus thermocatenulatus, Geobacillus thermoleovorans, Geobacillus kaustophilus, Geobacillus thermoglucosidasius and Geobacillus thermodenitrificans. Subsequently, other species have been added to the genus, i.e. Geobacillus caldoxylosilyticus, which was originally trivially named 'Bacillus caldoxylolyticus', then transferred to Saccharococcus caldoxylosilyticus (Ahmad et al., 2000), and is now regarded as G. caldoxylosilyticus (Fortina et al., 2001), and lastly Geobacillus toebii (Sung et al., 2002). Not surprisingly, most microbiologists seek to isolate thermophiles from 'hot' environments; however, it has recently been shown that extremely thermophilic bacilli are present in cool soil environments at population levels that preclude them being contaminants from other environments (Marchant et al., 2002a, b).

Thermophiles can be categorized as being one of three types: (i) those that are restricted biogeographically and relaxed biogeochemically, (ii) those that are relaxed biogeographically and restricted biogeochemically or (iii) those that are relaxed biogeographically and relaxed biogeochemically. The thermophilic geobacilli fall into the last group because they are widely distributed and not restricted to specialized nutritional environments. Careful examination of the soil environment for thermophilic microorganisms has shown that the diversity is large and that 
there are organisms present that do not fit into the confines of Geobacillus species as recently recognized. In this paper we describe a novel species, Geobacillus debilis sp. nov., isolated from a cool soil environment in Northern Ireland, UK, belonging to a distinct Geobacillus genus subgroup. In addition, following comparison of $16 \mathrm{~S}$ rRNA gene sequences of several geobacilli with the sequences of strains of Bacillus pallidus we suggest reassigning Bacillus pallidus to Geobacillus pallidus comb. nov.

Soil samples were collected from a site in Northern Ireland within an established mixed wet meadow area, which had been undisturbed for at least 15 years (Irish Grid reference C881 215) and from a similarly undisturbed adjacent site under mixed coniferous and deciduous trees with no ground cover (Irish Grid reference C881 216). The soil type at the sites was basalt till and the samples were taken at a depth of $50 \mathrm{~mm}$ below the surface.

One hundred milligrams of soil sample was suspended in $50 \mathrm{ml}$ sterile Ringer's solution (Oxoid) containing $0 \cdot 1 \%$ Triton X-100 and placed in a sonicating bath (KS100; Kerry Ultrasonics Ltd) for $10 \mathrm{~min}$. One millilitre of the sample was serially diluted in Ringer's solution and spread plates were prepared on nutrient broth (Oxoid) at $\mathrm{pH} 6 \cdot 8$ $7 \cdot 2$ solidified with $0 \cdot 8 \%$ Gellan Gelrite gum (Sigma) and incubated at $70{ }^{\circ} \mathrm{C}$ for $24 \mathrm{~h}$ under aerobic conditions. Resulting colonies were isolated either onto specialized Bacillus medium (Leighton \& Doi, 1971) or trypticase soya broth solidified with agar or Gelrite Gellan gum (Sigma) and further purified before being stored as stock cultures either at room temperature or at $4{ }^{\circ} \mathrm{C}$.

Morphological and biochemical characterization of the isolates designated F10 (from the meadow site) and $\mathrm{Tf}^{\mathrm{T}}$ (from the wooded site) were carried out using standard methods as described by Marchant et al. (2002b). In order to allow longer incubation times for the biochemical tests, the cultures were incubated at $60^{\circ} \mathrm{C}$ rather than at the higher temperatures of $60-70{ }^{\circ} \mathrm{C}$ at which the organisms are able to grow.

DNA was extracted from pure cultures of the organisms and the 16S rRNA gene sequences were determined as described by Marchant et al. (2002b). DNA extraction from cultured bacteria was performed using a BIO 101 Inc. Soil DNA extraction kit. PCR was carried out using standard methods with the universal reverse primer $1492 \mathrm{R}$ with Bacteria-specific primer 27F (Bond et al., 2000) for the 16S rRNA gene. PCR amplification was carried out in reaction mixtures containing $0.2 \mathrm{mM}$ each dNTP, $1.5 \mathrm{mM} \mathrm{MgCl}_{2}$, $25 \mu \mathrm{M}$ each primer, $1 \mu \mathrm{l}$ template DNA and $2.5 \mathrm{U}$ Taq polymerase in a final volume of $100 \mu \mathrm{l}$ PCR buffer. Thermocycling was carried out in a Whatman Biometra $\mathrm{T}$ personal thermocycler under the following conditions: initial denaturation at $95^{\circ} \mathrm{C}$ for $120 \mathrm{~s}$, followed by 20 cycles of denaturation at $95^{\circ} \mathrm{C}$ for $60 \mathrm{~s}$, primer annealing at $45^{\circ} \mathrm{C}$ for $45 \mathrm{~s}$, elongation at $72{ }^{\circ} \mathrm{C}$ for $90 \mathrm{~s}$ with a final extension at $72{ }^{\circ} \mathrm{C}$ for $600 \mathrm{~s}$. PCR products were run on $1 \cdot 2$ or $2 \%$ agarose gels containing ethidium bromide.

DNA sequencing was carried out directly on purified PCR products. Three forward and three reverse sequencing primers were used (Marchant et al., 2002b). The sequencing reactions were carried out and analysed using the ABI Prism 3100 Genetic Analyzer system as specified by the manufacturer. The genomic $\mathrm{G}+\mathrm{C}$ ratio was determined using HPLC by DSMZ, Braunschweig, Germany.

Obligately thermophilic bacilli were easily isolated in large numbers from the cool soil environments examined (Marchant et al., 2002a, b). The strains isolated showed temperature ranges for visible growth of $40-75^{\circ} \mathrm{C}$ and had extremely high growth rates with minimum generation times of less than $30 \mathrm{~min}$ at $70^{\circ} \mathrm{C}$. Many of the isolates could be readily assigned to existing Geobacillus species (Nazina et al., 2001; Fortina et al., 2001) on the basis of morphology, metabolic characteristics and 16S rRNA gene sequences. Two isolates, $\mathrm{F} 10$ and $\mathrm{Tf}^{\mathrm{T}}$, showed low 16S rRNA gene sequence similarity with any recognized Geobacillus species, showing $93 \%$ similarity to a sequence for G. stearothermophilus (AY297092) and thus indicating a more distant phylogenetic relationship. It has been proposed that sequence similarity below $95 \%$ indicates a novel species (Fogel et al., 1999), although Stackebrandt \& Goebel (1994) set the threshold at $97 \%$; this suggests that strains $\mathrm{F} 10$ and $\mathrm{Tf}^{\mathrm{T}}$ represent a novel species of the genus Geobacillus. A higher sequence similarity of $99 \%$ was given for a strain given the name 'Bacillus thermozeamaize' (unpublished; accession no. Y288912) isolated from corn steep liquor and that was presumably a thermophile. Construction of phylogenetic trees using neighbour-joining (Saitou \& Nei, 1987), maximum-likelihood (Felsenstein, 1981, 1988, 1996) and parsimony (Felsenstein, 1996) methods indicated that strains $\mathrm{F} 10$ and $\mathrm{Tf}^{\mathrm{T}}$ represent a novel species, for which we propose the name Geobacillus debilis sp. nov. However, G. debilis shows close affinities to Bacillus pallidus, which we propose should become Geobacillus pallidus comb. nov. (Fig. 1). G. debilis strains F10 and $\mathrm{Tf}^{\mathrm{T}}$ each show $91 \% 16 \mathrm{~S}$ rRNA gene sequence similarity to the sequence of $G$. pallidus. Comparison of the mean distance analysis tree in Fig. 1 with the tree in Nazina et al. (2001) shows similar relationships. In both cases, G. kaustophilus, G. thermoleovorans, G. thermocatenulatus, G. subterraneus, G. uzenensis and G. thermodenitrificans form a closely related cluster. In addition, G. caldoxylosilyticus and Bacillus (Geobacillus) pallidus occupy similar relative positions in both trees, with subsequently described G. toebii and G. debilis fitted close by in our tree. We have been able to confirm these relationships in a second phylogenetic tree constructed by mean distance analysis (data not shown).

The original description of the genus Geobacillus by Nazina et al. (2001) gave species as rod-shaped cells of varying dimensions but less than $10 \mu \mathrm{m}$ long. Although there are references to these thermophilic bacilli producing chains of cells, some isolates produce enormously long, undivided 


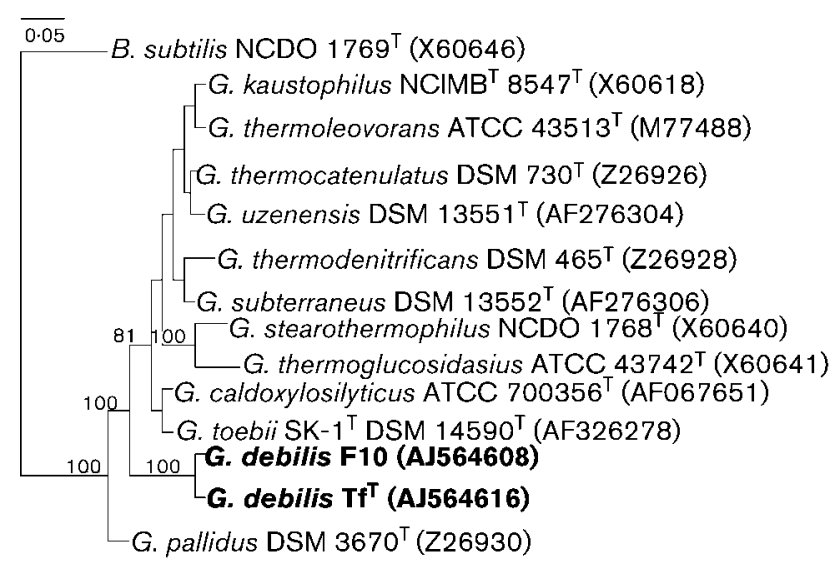

Fig. 1. Phylogenetic analysis of thermophilic bacterial isolates $\mathrm{F} 10$ and $\mathrm{Tf}^{\top}$ obtained from Northern Ireland soil. The tree topology is based on neighbour-joining analysis of 16S rRNA gene sequences. Database sequence accession numbers are given in parentheses. Bacillus subtilis was used as an outgroup. Only bootstrap values $>80 \%$ are shown at nodes (based on 1000 bootstrap resamplings). Bar, 0.05 substitutions per nucleotide position.

flexuous cells (Marchant et al., 2002b). In the case of $G$. debilis, no elongated cells have been observed and the rods were $0 \cdot 5-1 \mu \mathrm{m}$ wide by $1-14 \mu \mathrm{m}$ long. Spore formation is also a defining character of Bacillus and Geobacillus and in many strains sporulation is copious and readily initiated. We have only been able to show the production of spores in G. debilis following prolonged storage of plate cultures. The spores are produced singly and are not swollen beyond the size of the cells. Cells are motile and produce flat, cream-coloured colonies with smooth margins. Cells stain Gram-negative, but variable Gram-staining reactions are the norm for this group of Gram-positive bacteria.

G. debilis shows a temperature range for growth of $50-70{ }^{\circ} \mathrm{C}$, which is a rather narrower range than for other species in the genus. The organism is a strict aerobe and does not use nitrate or sulphate as a terminal electron acceptor.

Detailed characteristics of the two strains of G. debilis used in this study are shown in Table 1. Morphological and biochemical characterizations, including alkane utilization (pentane, hexane, heptane, dodecane, hexadecane, octadecane and nonadecane), were carried out using standard methods as described by Marchant et al. (2002b). Characteristics of all recognized Geobacillus species are shown in Table 2.

\section{Reassignment of B. pallidus to G. pallidus comb. nov.}

During screening of numerous soil thermophile isolates (Rahman et al., 2004), several showed close 16S rRNA gene sequence similarity to the thermophilic B. pallidus, which was originally isolated from thermophilic treated wastes
Table 1. Characteristics of Geobacillus debilis sp. nov. strains $\mathrm{Tf}^{\top}$ and $\mathrm{F} 10$

+ , Positive; - , negative; $+{ }^{\mathrm{w}}$, weakly positive; $\mathrm{G}$, growth but no acid production. No acid production by either strain from mannose, fructose, maltose, lactose, sucrose, galactose, glycerol or cellobiose. Both strains stained Gram-negative and gave negative results for Voges-Proskauer, indole production, urea hydrolysis and utilization of amylopectin, cellulose, citrate, sodium acetate, starch, glycogen and Tween 80 . Both strains grew at $50-70{ }^{\circ} \mathrm{C}$ and gave positive results for sporulation, motility, production of acid from raffinose, utilization of myo-inositol and the oxidase and catalase tests.

\begin{tabular}{|lcc|}
\hline Characteristic & Strain Tf $^{\mathbf{T}}$ & Strain F10 \\
\hline Cell size $(\mu \mathrm{m})$ & $0 \cdot 5 \times 1 \cdot 1-10 \cdot 9$ & $1 \cdot 1 \times 1 \cdot 1-14 \cdot 2$ \\
Production of acid from: & - & $-(\mathrm{G})$ \\
Glucose & $-(\mathrm{G})$ & - \\
Xylose & $+{ }^{\mathrm{w}}$ & - \\
Ribose & $+{ }^{\mathrm{w}}$ & + \\
Trehalose & $+{ }^{\mathrm{w}}$ & $-(\mathrm{G})$ \\
Sorbitol & $-(\mathrm{G})$ & - \\
Rhamnose & - & $+{ }^{\mathrm{w}}$ \\
Arabinose & & - \\
Utilization of: & + & $+{ }^{\mathrm{w}}$ \\
Carboxymethyl cellulose & - & + \\
Sodium formate & - & $+{ }^{\mathrm{w}}$ \\
Casein & $+{ }^{\mathrm{w}}$ & - \\
Methyl red test & + & - \\
Gelatin liquefaction & $+{ }^{\mathrm{w}}$ & \\
Alkane utilization & & \\
\hline
\end{tabular}

and was described by Scholz et al. (1987). B. pallidus has subsequently been employed in studies of thermostable enzymes and biodegradation studies including breakdown of 2-propanol (Bustard et al., 2002). A close examination of the published characteristics of B. pallidus (Table 2) together with the morphological description (Scholz et al., 1987) and with the sequence similarity for the 16S rRNA gene available on the European Bioinformatics Institute database and with these of our Geobacillus isolates obtained from soil strongly suggests that $B$. pallidus should be transferred and renamed G. pallidus. A phylogenetic tree for Geobacillus species including G. pallidus presented in Fig. 1 indicates the affinity of G. pallidus with G. caldoxylosilyticus, G. toebii and G. debilis.

\section{Description of Geobacillus debilis sp. nov.}

Geobacillus debilis (de'bil.is. L. masc. adj. debilis weak or feeble, referring to the restricted substrate range for this species).

Gram-negative rods, $0 \cdot 5-1 \cdot 0 \mu \mathrm{m}$ wide by $1 \cdot 0-14 \cdot 0 \mu \mathrm{m}$ long, motile, spores sparsely produced terminally, sporangium not swollen. Colonies flat, cream-coloured with smooth margins. Growth occurs at $50-70{ }^{\circ} \mathrm{C}$, with an optimum above $60{ }^{\circ} \mathrm{C}$. Obligate aerobe. The DNA G+C 
Table 2. Characteristics of all recognized Geobacillus species including G. debilis sp. nov. and G. pallidus comb. nov.

Strains: 1, G. debilis sp. nov. DSM $16016^{\mathrm{T}}$ (data from this study); 2, G. pallidus comb. nov. DSM 3670 (data from Scholz et al., 1987); 3, G. toebii DSM $14590^{\mathrm{T}}$ (Sung et al., 2002); 4, G. kaustophilus NCIMB 8547 ${ }^{\mathrm{T}}$ (Sunna et al., 1997); 5, G. caldoxylosilyticus ATCC $700356^{\mathrm{T}}$ (Ahmad et al., 2000); 6, G. thermoglucosidasius ATCC $43742^{\mathrm{T}}$ (Suzuki et al., 1983); 7, G. stearothermophilus NCDO 1768 ${ }^{\mathrm{T}}$; 8, G. thermoleovorans ATCC $43513^{\mathrm{T}}$; 9, G. thermodenitrificans DSM 465 ${ }^{\mathrm{T}}$; 10, G. uzenensis DSM 13551 ${ }^{\mathrm{T}}$; 11, G. subterraneus DSM 13552 ${ }^{\mathrm{T}}$; 12 , G. thermocatenulatus DSM $730^{\mathrm{T}}$. Unless indicated otherwise, data are from Nazina et al. (2001) and White et al. (1993). +, Positive; - , negative; $+{ }^{\mathrm{w}}$, weakly positive; $\mathrm{d}$, variable between strains; $\mathrm{d}^{\mathrm{w}}$, weak variable reaction between strains; ND, not determined.

\begin{tabular}{|c|c|c|c|c|c|c|c|c|c|c|c|c|}
\hline Characteristic & 1 & 2 & 3 & 4 & 5 & 6 & 7 & 8 & 9 & 10 & 11 & 12 \\
\hline Cell width $(\mu \mathrm{m})$ & $0 \cdot 5-1$ & $0 \cdot 8-0 \cdot 9$ & $0 \cdot 7-1$ & $1 \cdot 5$ & $0 \cdot 7-1$ & $0 \cdot 5-1 \cdot 2$ & $0 \cdot 6-1$ & $0 \cdot 7-1$ & $0 \cdot 5-1$ & $0 \cdot 9-1 \cdot 3$ & $1-1 \cdot 5$ & $0 \cdot 5-1 \cdot 2$ \\
\hline Cell length $(\mu \mathrm{m})$ & $1 \cdot 0-14 \cdot 2$ & $2-5$ & $3-7$ & $3 \cdot 5$ & $3->100$ & $3-7$ & $2-3 \cdot 5$ & $1 \cdot 5-3 \cdot 5$ & $1 \cdot 5-2 \cdot 5$ & $4 \cdot 7-8$ & $4 \cdot 7-7$ & $3-7$ \\
\hline Motility & + & + & + & - & - & + & + & - & ND & + & + & + \\
\hline Temperature range for growth $\left({ }^{\circ} \mathrm{C}\right)$ & $50-70$ & $30-70$ & $44-80$ & $40-75$ & $43-80$ & $42-69$ & $37-65$ & $40-80$ & $45-70$ & $45-65$ & $45-65$ & $42-69$ \\
\hline DNA G $+\mathrm{C}$ content $(\mathrm{mol} \%)$ & 50 & $39-41$ & 44 & 54 & 44 & $45-46$ & 52 & $52-58$ & $48-52$ & $50-52$ & $50-52$ & 55 \\
\hline \multicolumn{13}{|l|}{ Acid produced from: } \\
\hline Cellobiose & - & - & - & + & + & + & - & + & + & + & + & + \\
\hline Maltose & - & $\mathrm{d}$ & - & + & + & + & + & + & + & + & ND & + \\
\hline Mannose & - & - & + & + & + & + & + & $\mathrm{d}$ & + & + & + & + \\
\hline Sucrose & - & $\mathrm{ND}$ & + & + & $\mathrm{d}$ & + & + & d & $\mathrm{d}$ & ND & $\mathrm{ND}$ & $\mathrm{ND}$ \\
\hline Trehalose & + & $\mathrm{d}$ & - & + & + & + & $\mathrm{d}$ & + & + & + & ND & ND \\
\hline Xylose & - & - & - & + & + & + & - & $\mathrm{d}$ & + & - & - & + \\
\hline Arabinose & $\mathrm{d}^{\mathrm{w}}$ & - & - & - & + & - & - & d & + & + & - & - \\
\hline Ribose & $d^{\mathrm{w}}$ & - & - & - & - & - & ND & d & + & + & + & ND \\
\hline Citrate used & - & - & - & + & - & - & $\mathrm{d}$ & - & ND & - & - & $\mathrm{d}$ \\
\hline \multicolumn{13}{|l|}{ Hydrolysis of: } \\
\hline Casein & d & - & - & + & + & + & $\mathrm{d}$ & + & - & - & - & + \\
\hline Gelatin & d & - & - & + & - & - & $\mathrm{d}$ & - & $\mathrm{ND}$ & + & - & - \\
\hline Starch & - & $+{ }^{w}$ & - & + & + & + & + & + & + & + & + & + \\
\hline Alkane utilization & $d^{\mathrm{w}}$ & ND & $\mathrm{d}^{\mathrm{w}}$ & + & + & ND & + & + & ND & + & + & + \\
\hline
\end{tabular}

content is $49.9 \mathrm{~mol} \%$. Production of acid from raffinose and trehalose, and also from ribose, sorbitol and arabinose in some strains. No utilization of starch but casein and gelatin used in some strains; very limited use of alkanes. Habitat, soil.

The type strain is $\operatorname{Tf}^{\mathrm{T}}$ (=DSM $16016^{\mathrm{T}}=\mathrm{NCIMB} 13995^{\mathrm{T}}$ ); strains have been isolated from $50 \mathrm{~mm}$ undisturbed subsurface soil samples from Northern Ireland.

\section{Description of Geobacillus pallidus (Scholz et al. 1988) Banat, Marchant and Rahman comb. nov.}

Basonym: Bacillus pallidus Scholz et al. 1988.

The description is identical to that given for the genus Geobacillus by Nazina et al. (2001) and the species description given by Scholz et al. (1987). The type strain is $\mathrm{H} 12^{\mathrm{T}}\left(=\right.$ ATCC $\left.51176^{\mathrm{T}}=\mathrm{DSM} 3670^{\mathrm{T}}=\mathrm{LMG} 19006^{\mathrm{T}}\right)$.

\section{Acknowledgements}

T.J.R. gratefully acknowledges the award of a Vice Chancellor's Scholarship from the University of Ulster. We wish to thank Dr C. J. Hack for providing assistance with the construction of phylogenetic trees.

\section{References}

Ahmad, S., Scopes, R. K., Rees, G. N. \& Patel, B. K. C. (2000). Saccharococcus caldoxylosilyticus sp. nov., an obligately thermophilic, xylose-utilizing, endospore-forming bacterium. Int $J$ Syst Evol Microbiol 50, 517-523.

Bond, P. L., Smriga, S. P. \& Banfield, J. F. (2000). Phylogeny of microorganisms populating a thick, subaerial predominantly lithotrophic biofilm at an extreme acid mine drainage site. Appl Environ Microbiol 66, 3842-3849.

Bustard, M. T., Whiting, S., Cowan, D. A. \& Wright, P. C. (2002). Biodegradation of high-concentration isopropanol by a solventtolerant thermophile, Bacillus pallidus. Extremophiles 6, 319-323.

Claus, D. \& Berkeley, R. C. W. (1986). Genus Bacillus Cohn 1872, $174^{\mathrm{AL}}$. In Bergey's Manual of Systematic Bacteriology, vol. 2, pp. 1105-1139. Edited by P. H. A. Sneath. Baltimore: Williams \& Wilkins.

Felsenstein, J. (1981). Evolutionary trees from DNA sequences: a maximum likelihood approach. J Mol Evol 17, 368-376.

Felsenstein, J. (1988). Phylogenies from molecular sequences: inference and reliability. Anпu Rev Genet 22, 521-565.

Felsenstein, J. (1996). Inferring phylogeny from protein sequences by parsimony, distance and likelihood methods. Methods Enzymol 266, 368-382.

Fogel, G. B., Collins, C. R., Li, J. \& Brunk, C. F. (1999). Prokaryotic genome size and SSU rDNA copy number: estimation of microbial relative abundance from a mixed population. Microb Ecol 38, 93-113. 
Fortina, M. G., Mora, D., Schumann, P., Parini, C., Manachini, P. L. \& Stackebrandt, E. (2001). Reclassification of Saccharococcus caldoxylosilyticus as Geobacillus caldoxylosilyticus (Ahmed et al. 2000) comb. nov. Int J Syst Evol Microbiol 51, 2063-2071.

Leighton, T. J. \& Doi, R. H. (1971). The stability of messenger ribonucleic acid during sporulation in Bacillus subtilis. J Biol Chem 246, 3189-3195.

Marchant, R., Banat, I. M., Rahman, T. J. \& Berzano, M. (2002a). What are high temperature bacteria doing in cold environments? Trends Microbiol 10, 120-121.

Marchant, R., Banat, I. M., Rahman, T. J. \& Berzano, M. (2002b). The frequency and characteristics of highly thermophilic bacteria in cool soil environments. Environ Microbiol 4, 595-602.

Nazina, T. N., Tourova, T. P., Poltaraus, A. B. \& 8 other authors (2001). Taxonomic study of aerobic thermophilic bacilli: descriptions of Geobacillus subterraneus gen. nov., sp. nov. and Geobacillus uzenensis sp. nov. from petroleum reservoirs and transfer of Bacillus stearothermophilus, Bacillus thermocatenulatus, Bacillus thermoleovorans, Bacillus kaustophilus, Bacillus thermoglucosidasius and Bacillus thermodenitrificans to Geobacillus as the new combinations G. stearothermophilus, G. thermocatenulatus, G. thermoleovorans, $G$. kaustophilus, G. thermoglucosidasius and G. thermodenitrificans. Int J Syst Evol Microbiol 51, 433-446.

Rahman, T. J., Marchant, R. \& Banat, I. M. (2004). Distribution and molecular investigation of highly thermophilic bacteria associated with cool soil environments. Biochem Soc Trans 32, 209-213.
Rainey, F. A., Fritze, D. \& Stackebrandt, E. (1994). The phylogenetic diversity of thermophilic members of the genus Bacillus as revealed by $16 \mathrm{~S}$ rDNA analysis. FEMS Microbiol Lett 115, 205-212.

Saitou, N. \& Nei, M. (1987). The neighbor-joining method: a new method for reconstructing phylogenetic trees. Mol Biol Evol 4, 406-425.

Scholz, T., Demharter, W., Hensel, R. \& Kandler, O. (1987). Bacillus pallidus sp. nov., a new thermophilic species from sewage. Syst Appl Microbiol 9, 91-96.

Stackebrandt, E. \& Goebel, B. M. (1994). A place for DNA-DNA reassociation and $16 \mathrm{~S}$ ribosomal RNA sequence analysis in the present species definition in bacteriology. Int J Syst Bacteriol 44, 846-849.

Sung, M.-H., Kim, H., Bae, J.-W. \& 9 other authors (2002). Geobacillus toebii sp. nov., a novel thermophilic bacterium isolated from hay compost. Int J Syst Evol Microbiol 52, 2251-2255.

Sunna, A., Tokajian, S., Burghardt, J., Rainey, F., Antranikian, G. \& Hashwa, F. (1997). Identification of Bacillus kaustophilus, Bacillus thermocatenulatus and Bacillus strain HSR as members of Bacillus thermoleovorans. Syst Appl Microbiol 20, 232-237.

Suzuki, Y., Kishigami, T., Inoue, K., Mizoguchi, Y., Eto, N., Takagi, M. \& Abe, S. (1983). Bacillus thermoglucosidasius sp. nov., a new species of obligately thermophilic bacilli. Syst Appl Microbiol 4, 487-495.

White, D., Sharp, R. J. \& Priest, F. G. (1993). A polyphasic taxonomic study of thermophilic bacilli from a wide geographical area. Antonie van Leeuwenhoek 64, 357-386. 